\title{
Intracellular increase of glutamate in neuroblatoma cells induced by polar substances of Galaxaura marginata (Rhodophyta, Nemaliales)
}

\author{
Enrique E. Rozas, * José C. Freitas \\ Departamento de Fisiologia, Instituto de Biociências, Universidade de São Paulo, \\ 05508-900 São Paulo-SP, Brasil
}

\begin{abstract}
RESUMO: "Aumento do glutamato intracelular induzido por substâncias polares de Galaxaura marginata (Rhodophyta, Nemaliales) em células de neuroblastoma". Quatro substâncias purificadas da alga vermelha Galaxaura marginata (Ellis \& Solander) Lamouroux, mediante HPLC, apresentaram propriedades neuroprotetoras e reguladoras da atividade mitocondrial quando testadas em células de neuroblastomas da cepa NEURO-2. Sob condições oxidativas basais, cada substância é capaz de modificar as concentrações intracelulares de glutamato, glutamina e alanina, sem alterar o equilíbrio oxidativo das células. Essas substâncias também produziram uma atividade bifásica no metabolismo mitocondrial, inibindo em baixas concentrações e estimulando em altas concentrações o mecanismo celular de redução do 3-(4,5-dimetiltiazol-2-il)-2,5-difeniltetrazol brometo (MTT), que indica atividade mitocondrial. Esses dados sugerem que o aumento do glutamato pode estar relacionado com a alteração do ciclo glutamato/glutamina induzido pelo bloqueio do transporte intracelular de glutamato. Além disso, nós sugerimos que essas substâncias exibem atividade neuroprotetora nas células de neuroblastoma, as protegendo do estresse oxidativo, produzido pela inibição dos transportadores de glutamato.
\end{abstract}

Unitermos: Galaxaura marginata, alga, neuroblastoma, mitocôndria, glutamato, glutamina, alanina.

\begin{abstract}
Four substances purified by HPLC from red seaweed Galaxaura marginata (Ellis \& Solander) Lamouroux showed neuroprotective and mitochondria regulatory properties in neuroblastoma NEURO-2A cells line. Under oxidative basal conditions, each substance is capable of modifying the glutamate, glutamine and alanine intracellular concentrations, without to alter the oxidative equilibrium of these cells. These substances, also, produced a biphasic activity in the mitochondrial metabolism, inhibiting, in lower concentrations and stimulating, in higher concentrations the mechanism of cellular 3-(4,5-dimethylthiazol-2-yl)-2,5-diphenyltetrazolium bromide (MTT) reduction, that indicates the mitochondrial activity. These data suggest that the intracellular increase of glutamate can be related to the glutamate/glutamine cycle alterations induced by the blockade of intracellular glutamate transport. Moreover, we suggested that there are substances, exhibiting neuroprotective activity in neuroblastoma cells, protecting them from oxidative stress produced by the inhibition of the glutamate transporters.
\end{abstract}

Keywords: Galaxaura marginata, seaweed, neuroblastoma, mitochondria, glutamate, glutamine, alanine.

\section{INTRODUCTION}

A wide variety of neurodegenerative diseases such as Alzheimer (AD), Parkinson, Huntington disease (HD), epilepsy and amyotrophic lateral sclerosis, are characterized by the accumulation of intracellular or extracellular protein aggregates (Forman et al., 2004). This proteins may produce a toxic effect by the formation of reactive oxygen species, such as hydrogen peroxide $\left(\mathrm{H}_{2} \mathrm{O}_{2}\right)$ that promote oxidative stress, depletion of glutathione (GSH), mitochondrial dysfunction and inflammatory responses, promoting apoptotic process in the brain cells (Smith et al., 1995). In this sense, in order to mitigate the oxidative disequilibrium produced in neurodegenerative disorders, the aqueous extracts of Halimeda (Ellis) Lamouroux (Chlorophyta, Caulerpales) and Bryothamnion triquetrum (S.G. Gmelim) (Rhodophyta, Ceramiales) showed protection against hydrogen peroxide-mediated cell death and neural death induced by methyl mercury chloride, as well as against methyl mercury chloride-mediated reactive oxygen species (ROS) generation (Fallarero et al., 2003). 
For this reason, seaweed substances have attracted attention as source of antioxidant, some examples are the carotenoids, phlorotannins and amino acids, which could be used in the cosmetic, food technology and biomedicine industries (Le Tutour, 1990). However, therapeutic strategies aimed to improve the cognitive symptoms of patients via choline supplementation, cholinergic stimulation or $\beta$-amyloid vaccination, have largely failed to reduce the oxidative stress in the neurodegenerative disorders (Hynd et al., 2004).

Notwithstanding, some evidence suggests that perturbations produced by the excitatory amino acid glutamate may underlies the pathogenic mechanisms of chronic neurodegenerative disorders such as HD, AD and epilepsy (Ceccon et al., 2000; Sepkuty et al., 2002). Therefore, as almost all neurons in the CNS carry the $\mathrm{N}$-methyl-aspartate (NMDA) subtype of ionotropic -glutamate receptors, this make it vulnerable to excessive activation of receptors leading to posterior cellular death (Danbolt, 2001). On the other hand, the $\mathrm{HD}$ and $\mathrm{AD}$ show mitochondria dysfunction in relation to the respective proteins, huntingtin and $\beta$-amyloid, that increases the mitochondrial permeability transition, the cytochrome c release, reduces cytochrome oxidase activity, elevates ROS and reduces ATP level (Choo et al., 2004; Cardoso et al., 2004). These altered activities are keys to the cell death and apoptotic process in neurodegenerative diseases as regulators of the energy production, intermediary metabolism, ion homeostasis, cell motility, cell proliferation, synthesis of lipid, amino acids and nucleotides (Nakagawa et al., 2000). In relation to these considerations, we report the intracellular increase of glutamate and the regulation of the mitochondrial activity in neuroblastoma cells by the polar substances of Galaxaura marginata.

\section{MATERIAL AND METHODS}

\section{Extract preparation}

The seaweed samples were collected by skin diving at depths of about $2 \mathrm{~m}$ in São Sebastião channel (45⒉ ' W; 26 49'S) along the northern coast of the State of São Paulo, Brazil, during Spring 2000. The samples were washed with fresh water to remove epiphytes and adherent salts and subsequently stored at $-20{ }^{\circ} \mathrm{C}$. The sample (900 g fresh weight) was homogenized in a blender with ethanol:acetic acid $(5: 1 \mathrm{v} / \mathrm{v})$, filtered through a Whatman No. 41 (Whatman Ltd; England), concentrated under reduced pressure in a rotary evaporator (Büchi, Switzerland) until the solvents were eliminated and partitioned two folds with hexane, to withdraw the apolar substances (Sheu et al., 1996). The polar fraction $(150 \mathrm{~g})$ obtained from this partition was filtered through a membrane of $1 \mathrm{KDa}$ cut off $\left(\right.$ Diaflo $^{\circledR}$, Amicon, Inc., USA) under $4.5 \mathrm{~kg} / \mathrm{cm}^{2}$ nitrogen pressure, producing $19.8 \mathrm{~g}$ of a yellow powder. Following, the ultrafiltrated polar fraction $(200 \mathrm{mg} / \mathrm{mL})$ was loaded in a column (3.4 x $1.5 \mathrm{~cm}$ i.d.) of strongly basic Amberlite IRA-400 AR (Rohm and Haas Co, USA). The column was eluted with $80 \mathrm{~mL}$ of water and then eluted with 80 $\mathrm{mL}$ of acetic acid $2 \mathrm{~N}$ to recover the anionic fraction $(9$ g) (Sato et al., 1996).

\section{Substances purification}

The anionic fraction $(200 \mu \mathrm{g})$ was injected in the LC-10A HPLC system (Shimadzu, Japan). The fractions were eluted from the C-18 column $(250 \times 4.6 \mathrm{~mm}$, $5 \mu$, ODS Hypersil, Supelco, Sigma), with acetonitrile (J.T. Baker, USA)(A) and water (B) in a linear solvent gradient from $0-100 \% \mathrm{~A}$, between 0 and $7 \mathrm{~min}, 100 \%$ A, between 7 and $10 \mathrm{~min}$, and $100-0 \%$, between 10 and $22 \mathrm{~min}$. The temperature was kept at $40^{\circ} \mathrm{C}$, the flow rate at $2 \mathrm{~mL} / \mathrm{min}$, and the fractions eluted from the column were monitored at $200 \mathrm{~nm}$ (Figure 1). Each peak were manually collected, lyophilized, and kept at $-20{ }^{\circ} \mathrm{C}$ until test. The peaks collected represented the $0.0012 \%$ of the total weight of the seaweed sample.

\section{Cell culture}

Cell line from mouse neuroblastoma Neuro-2A was obtained from Oswaldo Cruz Institute Foundation, Rio do Janeiro, Brazil. The cells were grown in culture medium DMEM (Cultilab Ltda., Brazil) supplemented with $10 \%$ inactivated fetal bovine serum at $37^{\circ} \mathrm{C}$ in $5 \%$ $\mathrm{CO}_{2}$. The cells were cultured in $75 \mathrm{~cm}^{2}$ culture flask to confluence and harvested using a solution $0.05 \%$ trypsin and $0.02 \%$ EDTA in PBS. For experiments, $400 \mu \mathrm{L}$ of the harvested cells were cultured in 6 wells plate $(2 \mathrm{x}$ $10^{5}$ cells per well) for $48 \mathrm{~h}$. After culture, the medium was withdraw and the cells were incubated $4 \mathrm{hrs}$ with $0.5,1$ and $10 \mu \mathrm{g} / \mathrm{mL}$ (final concentration) of each algal peaks (T1, T2, T3 and T4) diluted in culture medium (n $=8$ ). A control plate was maintained for each test.

\section{Sample preparation}

At the end of the incubation, the medium was removed and preserved for analysis. The cells were centrifuged $10 \mathrm{~min}$ at $10,000 \mathrm{~g}$ at $4{ }^{\circ} \mathrm{C}$, the supernatant was decanted and the pellet rinsed twice with Milli-Q water. The pellet was diluted in $1.0 \mathrm{~mL}$ of Milli-Q water, sonicated $10 \mathrm{sec}$ at $50 \mathrm{~W}$ and an aliquot of $0.5 \mathrm{~mL}$ of the homogenate was taken for protein and glutathione (GSH) determination. The remaining of homogenate was added to $0.5 \mathrm{~mL}$ of $0.1 \mathrm{~N} \mathrm{HCl}$ in $95 \%$ methanol, centrifuged at $10,000 \mathrm{~g}$ for $10 \mathrm{~min}$ at $4{ }^{\circ} \mathrm{C}$ and the supernatant decanted into the micro-centrifuge tube. To the supernatant was added $0.2 \mathrm{~mL}$ of $0.5 \mathrm{M}$ sodium carbonate, mixed and centrifuged at 3,000 g for $5 \mathrm{~min}$. The supernatant was lyophilized and used for glutamate, glutamine and alanine analyses. 


\section{Glutathione and protein determination}

The glutathione concentration was determined in the incubation medium and the cell homogenate by a modification to the method of Ellman (Ellman, 1959). To $100 \mu \mathrm{L}$ of cell homogenate or incubation medium, 100 $\mu \mathrm{L}$ of Ellman's reagent [ $80 \mu \mathrm{g} / \mathrm{ml}$ of 5,5-dithio-bis(2nitrobenzoic acid) in $0.2 \mathrm{M}$ of sodium phosphate buffer, $\mathrm{pH}=8.0]$, prepared just prior to assay, was added and allowed to stand for $10 \mathrm{~min}$ at room temperature $(\mathrm{n}=.8)$. The 96 wells plates were then read using a Spectra Max 250 (Molecular Devices Corporation, USA) micro-platereader at $415 \mathrm{~nm}$ wavelength. The protein concentration was determined by the method described by Bradford (Bradford, 1976). To $50 \mu \mathrm{L}$ of cell homogenate or incubation medium, $200 \mu \mathrm{L}$ of Bradford reagent $(0.01 \%$ Coomassie blue, $4.7 \%$ ethanol, and $8.5 \%$ de phosphoric acid) prepared just prior to assay, was added and allowed to stand for $5 \mathrm{~min}$ at room temperature $(\mathrm{n}=8)$. The 96 wells plates were then read using a Spectra Max 250 (Molecular Devices Corporation, USA) micro-platereader at $595 \mathrm{~nm}$ wavelength. In both cases, standards curves for glutathione and albumin (to total protein) were realized in 10 to $200 \mu \mathrm{g} / \mathrm{mL}$ of concentration, as a reference to quantify the samples $(n=12)$.

\section{Amino acid determination}

The glutamate, glutamine and alanine determination was performed on LC-10A HPLC system (Shimadzu, Japan) equipped with a LC-10 solvent delivery system and Shimadzu RF-535 scanning fluorescence detector. The detector was set at an excitation wavelength of $340 \mathrm{~nm}$ and emission wavelength of $455 \mathrm{~nm}$. The amino acids were derivatized by a modification to the method of Roth (Roth, 1971). $100 \mu \mathrm{L}$ of $o$-phthaldialdehyde reagent solution (Sigma, USA) were added to supernatant of cells homogenized, diluted with $380 \mu \mathrm{L}$ of $0.05 \mathrm{M}$ of sodium tetraborate $(\mathrm{pH}=9.5)$, and then added $10 \mu \mathrm{L}$ of mercaptoethanol (5 $\mu \mathrm{L} / \mathrm{mL}$ in ethanol), prior to fluorescence analysis. 100 $\mu \mathrm{L}$ of the mixture were injected into the HPLC system. The elution was performed with $0.5 \mathrm{M}$ sodium acetate $(\mathrm{pH}=7.2)(\mathrm{A})$ and the mixture of $0.1 \mathrm{M}$ sodium acetate: acetonitrile: methanol $(46: 44: 10 \mathrm{v} / \mathrm{v})(\mathrm{pH}=7.2)(\mathrm{B})$. The elution gradient was $0-100 \% \mathrm{~B}$ in $0-10 \mathrm{~min}, 100 \%$ B 10-13 min and $100-0 \% \mathrm{~B}$ in 13-23 min. The flow rate was $2 \mathrm{~mL} / \mathrm{min}$ at $40{ }^{\circ} \mathrm{C}$ and the chromatographic separation column was a C-18 column Hypersil Supelco ( $250 \times 4.6 \mathrm{~mm}, 5 \mu$, ODS, Sigma). The standard were realized with $1 \mathrm{mg} / \mathrm{mL}$ of glutamine, glutamate or alanine (Sigma) and submitted to the same treatment of the samples $(n=8)$.

\section{MTT assay}

The neuroblastoma cells $\left(10 \times 10^{3}\right.$ cells/well $)$ were added into the each well of a 96 wells plate, conserving the column 1 and 12 to blank the plate reader. The plates were incubated in an atmosphere humidified at $37^{\circ} \mathrm{C}$ for $1-3 \mathrm{~d}$, at the end of these period 0.5 to $10 \mu \mathrm{g} / \mathrm{mL}$ (final concentration into the well) of the algal fractions (T1, T2, T3 e T4) were added. After 4 $\mathrm{h}$ de test the culture medium was removed, and $200 \mu \mathrm{L}$ of fresh culture medium and $20 \mu \mathrm{L}$ of MTT $(1.25 \mathrm{mg} /$ $\mathrm{mL}$ ) dissolved in PBS ( $\mathrm{pH} 7.4$ ) were added to each well. After $12 \mathrm{~h}$ of incubation, the medium was removed and dissolved the MTT-formazan adding $200 \mu \mathrm{L}$ of $0.01 \mathrm{~N}$ $\mathrm{HCl}$ /isopropanol. The absorbance values at $570 \mathrm{~nm}$ were determined with a plate Spectra Max 250 (Molecular Devices Corporation, USA) micro-plate-reader (Freshney and Freshney, 1996). Quadruplicate wells were used for each fraction dose and average values were obtained. The same experiment was repeated in four separate cultures, and the data were presented as the means \pm standard deviation of the four observation.

\section{Statistical analysis}

The data analyses were realized with the GraphPad Prism4 software. Statistical treatments were performed by two way ANOVA and the differences were evaluated using Bonferroni test. Differences with $p<0.05$ were considered statistically significant.

\section{RESULTS}

\section{Glutathione and protein determination}

The intracellular and extracellular protein concentration (Figure 2) and GSH/protein relationship (Figure 3) were not consistently altered for the fractions obtained from G. marginata (Figure 1). However, were observed a significant reduction, non dose-dependent, in the intracellular GSH level of the neuroblastoma cells treated with T4 (Figure 3, D). On the other hand, the cells exposed to T4 showed a slight intracellular increase of total protein (Figure 2, D) in respect to the control.

\section{Amino acid determination}

Cells incubated with $\mathrm{T} 1(10 \mu \mathrm{g} / \mathrm{mL})$ showed a significant increase in the glutamate and glutamine intracellular concentration, different of the alanine (Figure 4, A). The intracellular glutamate concentration increased in all T2 doses tested, the glutamine increased $62.4 \%$ and the alanine increased $13 \%$ upper the control when tested with $0.5 \mu \mathrm{g} / \mathrm{mL}$ of the T2 (Figure 4, B). T3 $(0.5 \mu \mathrm{g} / \mathrm{mL})$ increased in $14.4 \%$ the glutamate concentration, the glutamine increased $33.8 \%$ and alanine increased $41.8 \%$ when tested with $10 \mu \mathrm{g} / \mathrm{mL}$ of T3 (Figure 4, C). T4 increased the glutamate and glutamine levels, however, the alanine concentration, in the cells treated, never raising the concentration showed 
by the control, being $55.8 \%$ minor to the control in the highest tested concentration (Figure 4, D).

MTT assay: In order to determine the mitochondrial activity in neuroblastoma cells, the conversion of MTT to formazan crystal as function of mitochondrial respiratory chain reaction was measured. Exposed of neuroblastoma to increasing concentration of $\mathrm{T} 1, \mathrm{~T} 2, \mathrm{~T} 3$ and $\mathrm{T} 4$ resulted in a biphasic response of the mitochondrial activity (Figure, 5). In this sense, the mitochondrial activity was decreased $19.1 \pm 0.4 \%$ when exposed to $0.5 \mu \mathrm{L} / \mathrm{mL}$ of $\mathrm{T} 1\left(\mathrm{EC}_{50}: 4.9 \pm 0.8 \mu \mathrm{g} /\right.$ $\mathrm{mL}$ ) and increased $20.8 \pm 1 \%$ when exposed to $10 \mu \mathrm{g} /$ $\mathrm{mL}$ (Figure 5, A). T2 in the same dose $\left(\mathrm{EC}_{50}: 6.2 \pm 1.0\right.$ $\mu \mathrm{g} / \mathrm{mL})$ decreased $43.7 \pm 0.6 \%$ and increased $29.7 \pm 0.4$ $\%$ the mitochondrial activity (Figure 5, B). T3 $\left(\mathrm{EC}_{50}: 1.2\right.$ $\pm 0.6 \mu \mathrm{g} / \mathrm{mL})$ in the lowest dose decreased $21.4 \pm 0.3 \%$ and in the highest dose increased $12.3 \pm 0.4 \%$ the mitochondria activity (Figure 5, C). T4 decreased 32.9 $\pm 0.5 \%$ and increased $27.2 \pm 0.4 \%$ the mitochondrial activity compared to control (Figure 5, D).

\section{DISCUSSION}

In general, when we make references to the neurotoxic activity of the seaweed substances, relate this concept to cellular death, especially as consequence of neuroexcitatory effect of glutamate (Ankarcrona et al., 1995); however few works have studied the metabolic alteration induced by seaweed substances. The present findings demonstrated that four algal fractions (T1, T2, T3 and T4) increased the intracellular glutamate concentration; altering the glutamine and alanine concentration assembled to the mitochondrial activity in the mouse neuroblastoma cells. These fact, suggest that the algal fractions may be regulating the glutamate/ glutamine cycle and glutamate transport.

The mitochondrial metabolism was used to evaluate the algal fractions effects in the products of the neurotransmitters syntheses, and also to evaluate indirectly the relationship with the glutamate/glutamine cycle (Basselin and Robert-Gero, 1998; Bak et al., 2005). Thus, the results showed that the mitochondrial activity induced by T4 was dose-dependently related to the glutamate, glutamine and alanine intracellular concentration, decreased significantly the alanine, protein and intracellular glutathione concentration, without altering the extracellular glutathione. These results indicated that the metabolism was oriented to the production of glutamate and the equilibrium with the glutamine concentration was maintained through the glutamate/glutamine cycle (Broman et al., 2000). On the other hand, the mitochondrial activity of the cells exposed to T2, showed a dose-dependent relationship which coincided with the inversely proportional relationship between the glutamate, glutamine and alanina concentration, different to T4. This activity was observed in glutamatergic neuron which release glutamate independently of glutamine. In these cells, the synthesis of glutamate use the pyruvate carboxilation to replenishes the loss of $\alpha$-ketoglutarate in the tricarboxylic acid cycle and the transamination reactions to complete the synthesis with amino group donated by amino acids as alanina, leucine or isoleucine, imported from glia or neurons (Hassel and Brathe, 2000). These processes will explain the inversely proportional relationship between glutamate and alanina observed in the neuroblastoma cells tested with T2. Apparently glutamate glutamine cycle maintained the equilibrium between both amino acid, transforming the glutamate in glutamine, except when treated with $\mathrm{T} 2$, which stimulated the glutamate production from glutamine, besides alanina. Similar mitochondrial activities were observed when the cells were treated with $\mathrm{T} 1$ and $\mathrm{T} 3$ fractions. This fact suggested that $\mathrm{T} 2$ and $\mathrm{T} 4$ can be constituted by similar compound to $\mathrm{T} 1$ and $\mathrm{T} 3$, respectively.

In relation to the inhibition of the glutamate/ glutamine cycle by some fraction of $G$. marginata, only T2 decreased the glutamine concentration and increased the glutamate concentration dose-dependently. This suggests indirectly that $\mathrm{T} 2$ inhibited the glutamine synthetase enzyme, which converts the glutamate into glutamine, behaving as the specific inhibitor methionine sulfoxamine (Gibbs et al., 1996). The neurodegenerative diseases show an unbalance between release and uptake of glutamate that produce an over stimulation of the neurons, with the consequent cellular death and brain damage (Kemp and McKernan, 2002). Thus, the capacity of T2 to inhibit the glutamate/glutamine cycle and T4 to increase the glutamate uptake by the neuroblastoma cells, suggest that it is able to mitigate the metabolic alterations of the neurodegenerative diseases. Thus, the stable glutathione concentration in the medium indicated that oxidative stress does not occurs, only the management of the cellular metabolism for the energy production and the structures construction.

In conclusion, the four fractions obtained from G. marginata altered the intracellular concentration of glutamate, glutamine and alanine, without modify the cell oxidative equilibrium. However, the algal fractions induced a biphasic activity in the mitochondrial metabolism, inhibiting and stimulating the mitochondrial dehydrogenase. This biphasic activity, reported in studies of rat heart perfused, reveled a increase in the rate of glutamate/malate oxidation, followed by a decrease in this activity, due apparently to damage to Complex I at a site subsequent to the NADH dehydrogenase component (Veitch et al., 1992). However, the biphasic mitochondrial activity reported in the present work showed decrease activity followed by increase activity. Moreover, the capacity to reduce the oxidative stress in neuroblastoma cells, normally in this oxidative condition (Gouget et al., 2001), suggested that T2 and T4 may decrease redox function of the mitochondria. 

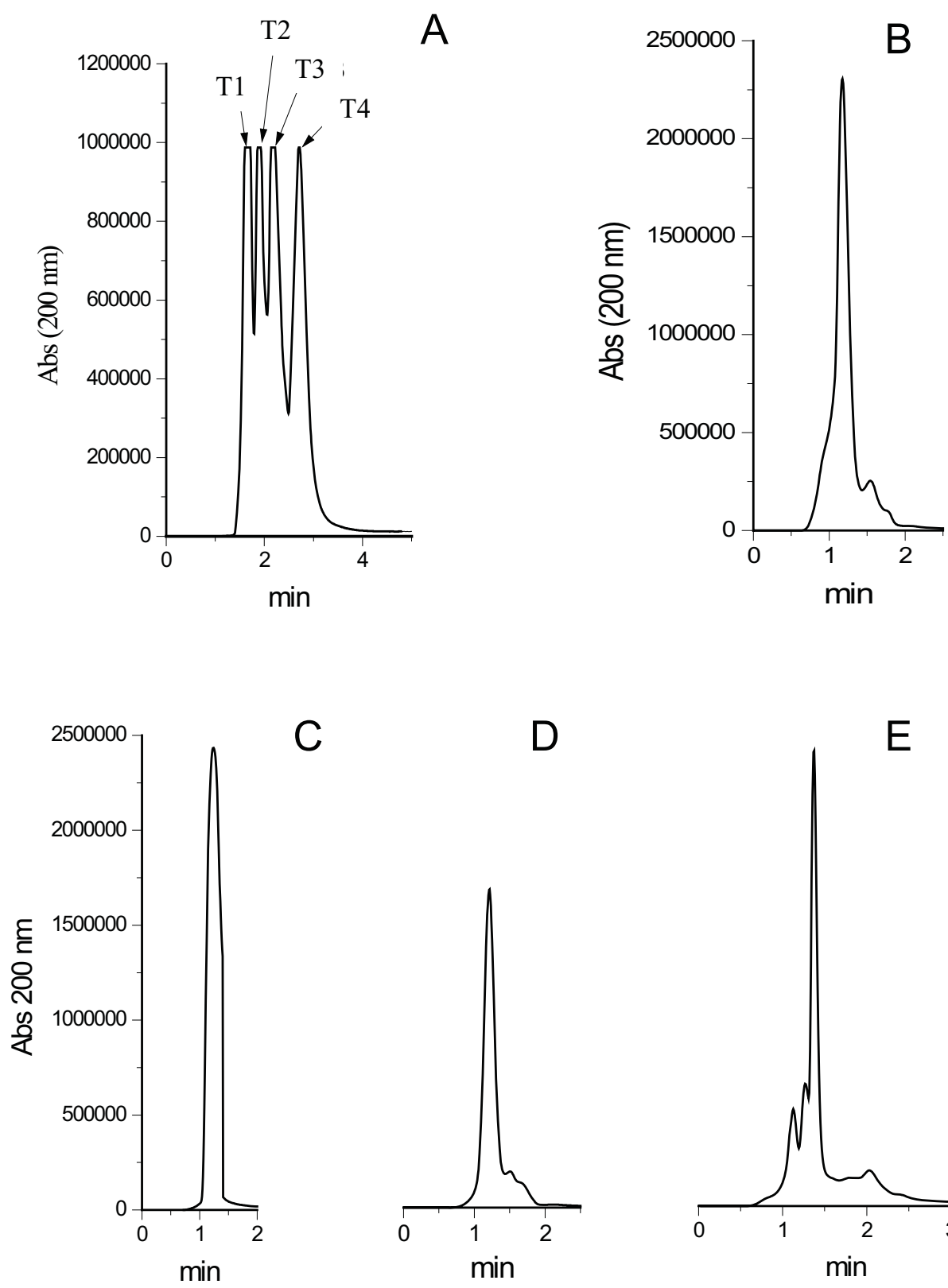

C

$\mathrm{D}$

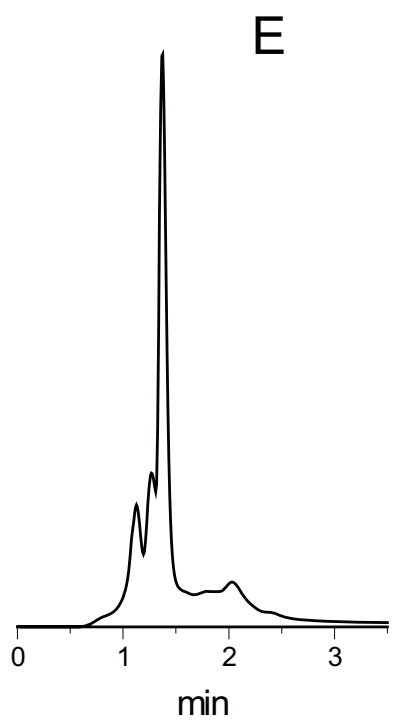

Figure 1. (A) HPLC elution profile of the anionic fraction of Galaxaura marginata. The profiles $\mathrm{B}, \mathrm{C}, \mathrm{D}$ and $\mathrm{E}$ are the elution profiles of T1, T2, T3 and T4, respectively, purified from the anionic fraction. Flow rate of $2 \mathrm{~mL} \mathrm{~min}^{-1}$ in $40{ }^{\circ} \mathrm{C}$, elution with a linear gradient of acetonitrile in water and the substances were detected to $200 \mathrm{~nm}$ of wavelength.

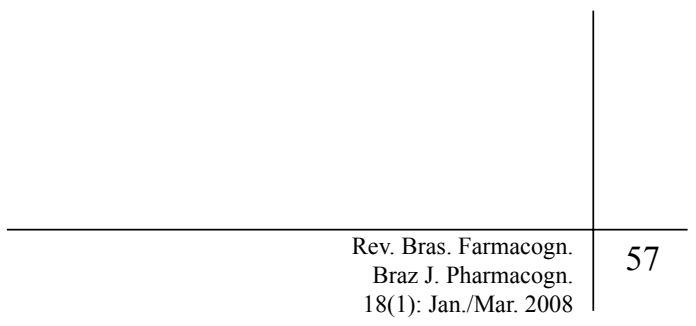


A

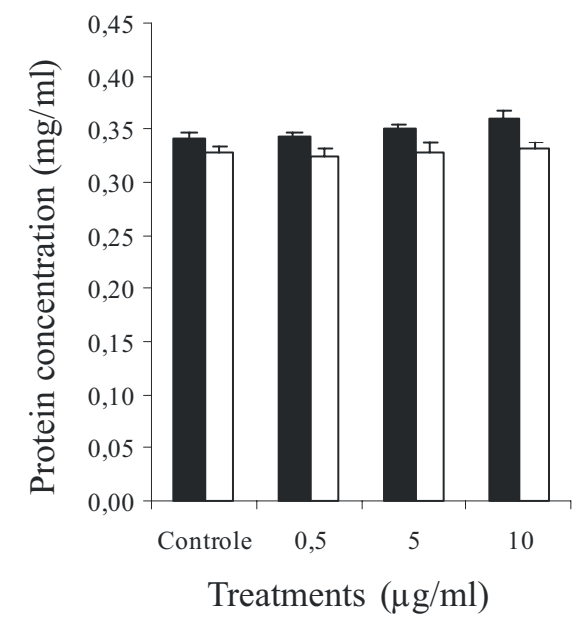

$\mathrm{C}$

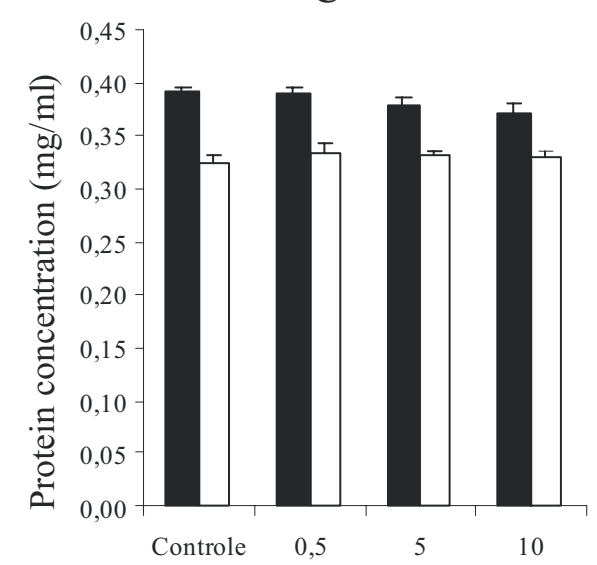

Treatments $(\mu \mathrm{g} / \mathrm{ml})$

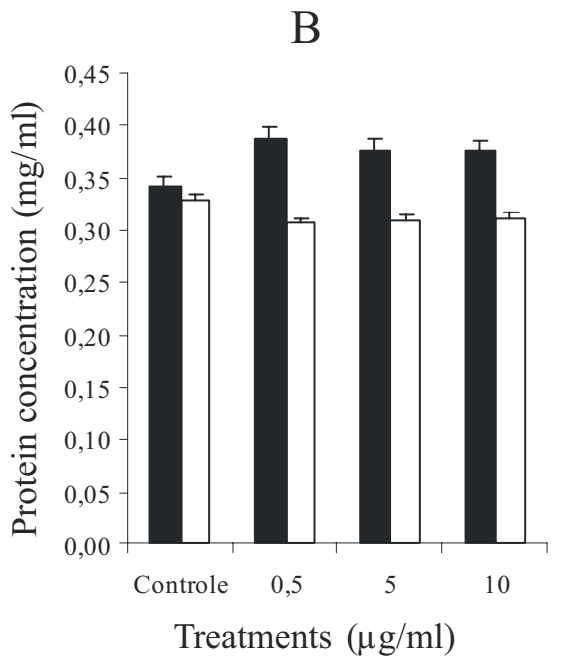

$\mathrm{D}$

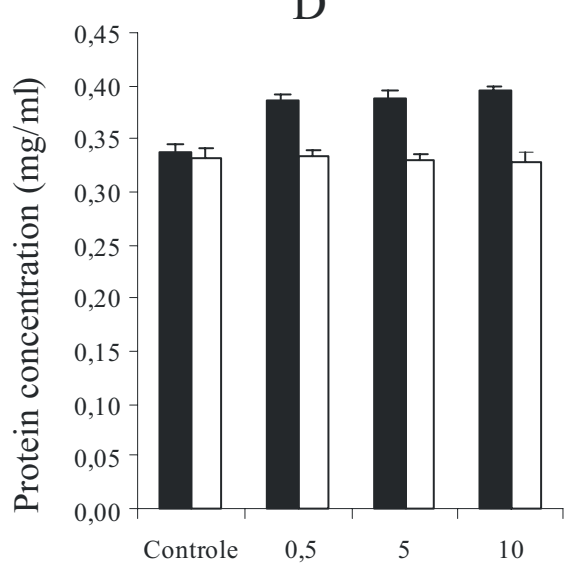

Treatments $(\mu \mathrm{g} / \mathrm{ml})$

Cell

Medium

Figure 2. Protein concentration of the neuroblastoma cell culture exposure to $0.5,5$ and $10 \mu \mathrm{g} /$ $\mathrm{mL}$ of T1 (A), T2 (B), T3 (C) and T4 (D). The intracellular and extracellular protein content was determined, after $4 \mathrm{~h}$ of incubation, according to the Bradford method (4). The data are shown as means \pm standard deviation $(\mathrm{n}=8)$ and Bonferroni test were used to compare to respective control $(p<0.05)$. 


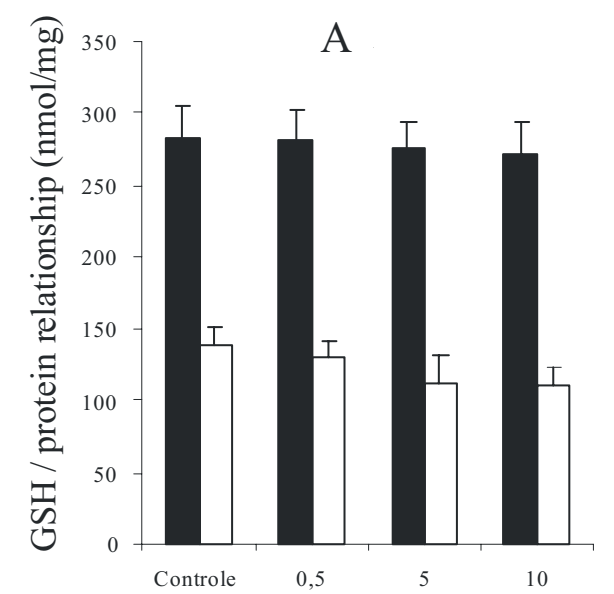

Treatments $(\mu \mathrm{g} / \mathrm{ml})$

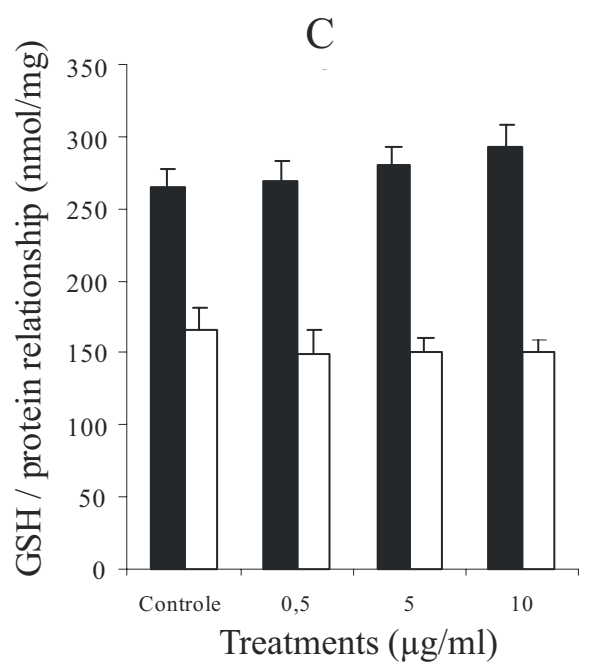

Cell

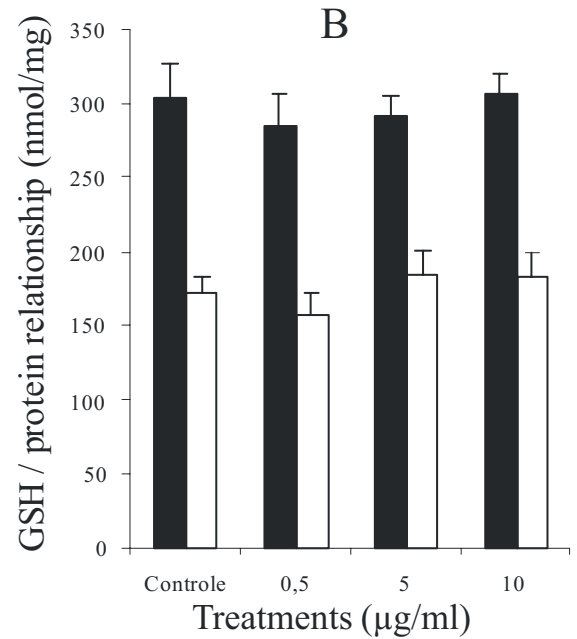

$\mathrm{D}$

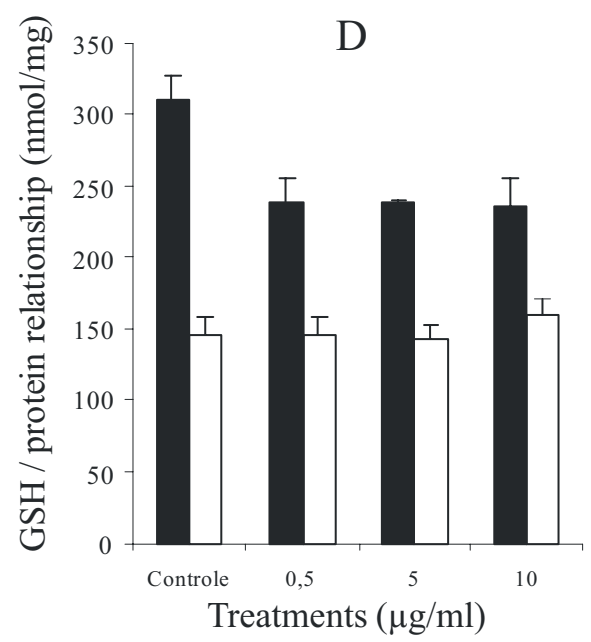

Medium

Figure 3. Glutathione/protein relationship of the neuroblastoma cell culture treated with $0.5,5$ and $10 \mu \mathrm{g} / \mathrm{mL}$ of T1 (A), T2 (B), T3 (C) and T4 (D). The intracellular and extracellular protein content was determined, after $4 \mathrm{~h}$ of incubation, according to the Ellman's reaction (10). The data are shown as means \pm standard deviation $(\mathrm{n}=8)$ and Bonferroni test were used to compare to respective control $(p<0.05)$.

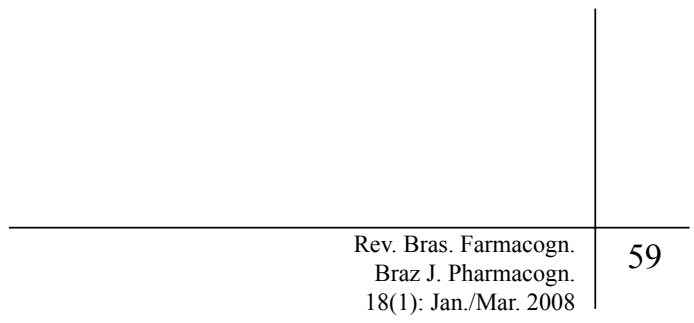



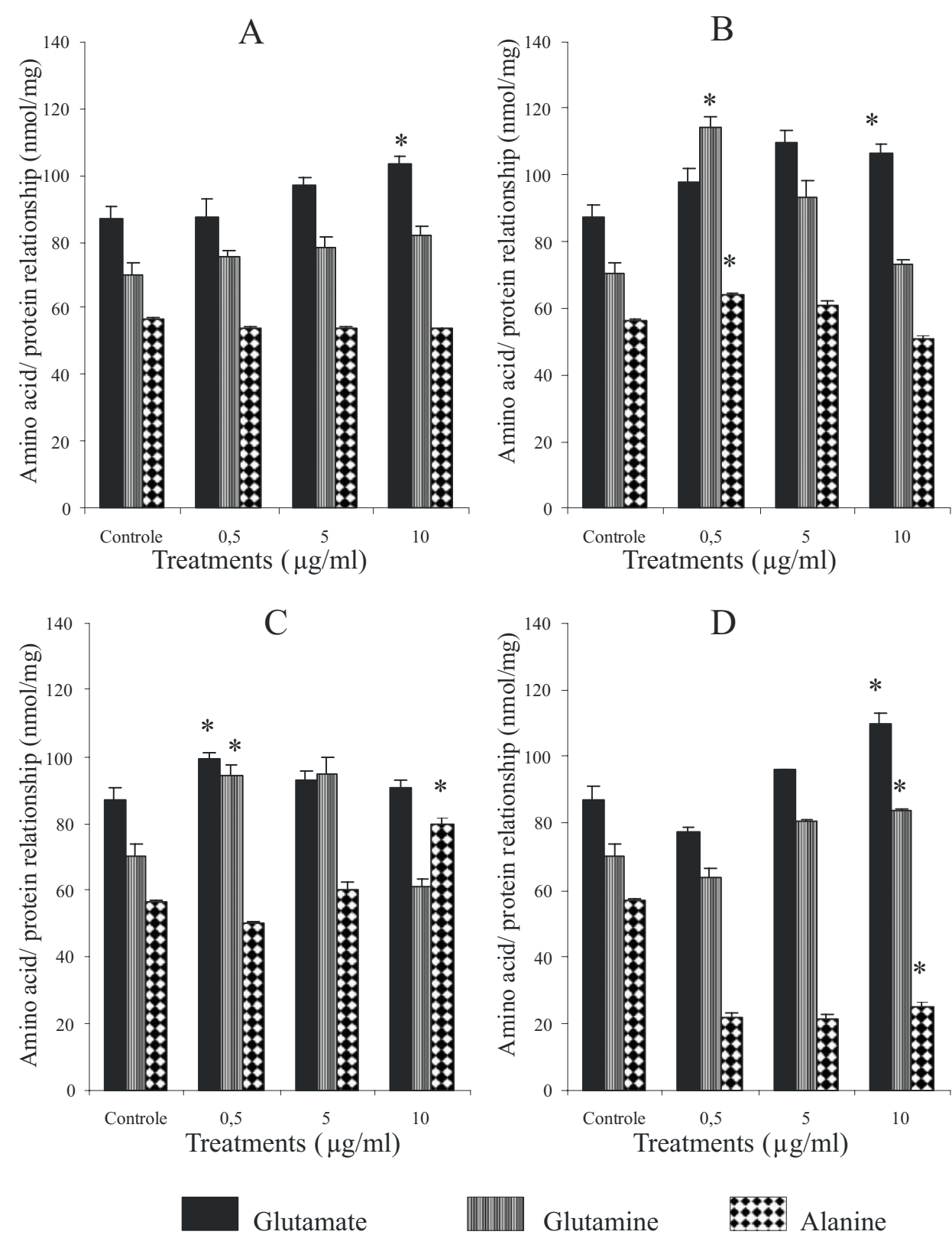

Alanine

Figure 4. Effect of T1 (A), T2 (B), T3 (C) and T4 (D) in the amino acid intracellular concentration of neuroblastoma cells treated with $0.5,5$ and $10 \mu \mathrm{g} / \mathrm{mL}$ of each substance. Dark bars represent the glutamate, striped bars glutamine and squared bars alanine concentration. Data are shown as means \pm standard deviation $(\mathrm{n}=8)$ and Bonferroni test were used to compare to respective control $(p<$ 0.05). (*) Indicate significant differences. 
A
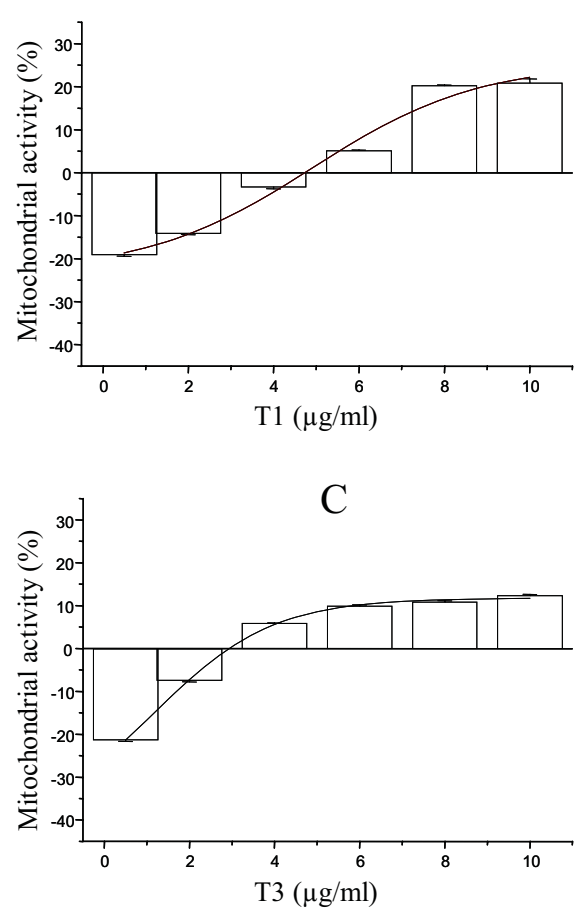

$\mathrm{B}$

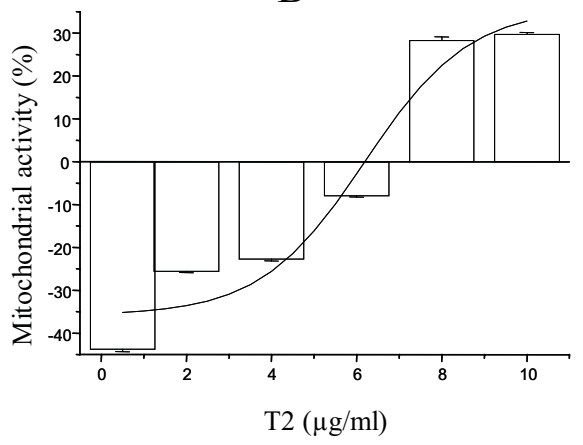

$\mathrm{D}$

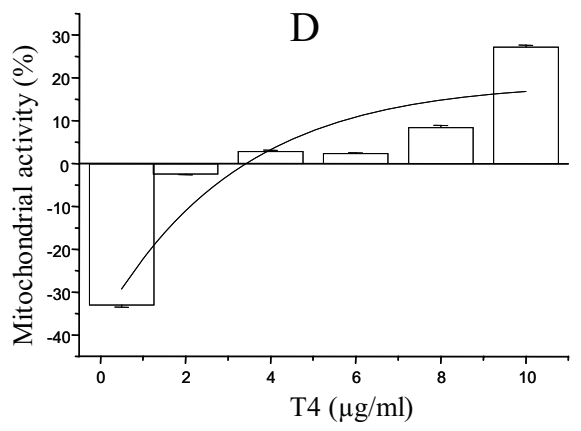

Figure 5. Effect of T1 (A), T2 (B), T3 (C) and T4 (D) in the mitochondrial activity of neuroblastoma cells exposed to $0.5-10 \mu \mathrm{g} / \mathrm{mL}$ of each substance. The mitochondrial activity was expressed as the percentage of the value in the control group, in relation to the MTT reduction. Quadruplicate wells were used for each substance dose and average values were obtained. The same experiment was repeated in four separate cultures, and the data were presented as the means \pm standard deviation of the four observation.

\section{ACKNOWLEDGMENTS}

This work was supported by FAPESP grants. Authors also express their gratitude to Dra. Regina P. Markus for the facilities in her laboratory and Dra. Zulma da Silva Ferreira for her technical help and discussion.

\section{REFERENCES}

Ankarcrona M, Dypbukt J, Bonfoco E, Zhivotovsky B, Orrenius S, Lipton S, Nicotera P 1995. Glutamateinduced neuronal death: A succession of necrosis or apoptosis depending on mitochondrial function. Neuron 15: 961-973.

Bak L, Sickmann H, Schousboe A, Waagepetersen H 2005. Activity of the lactate-alanine shuttle is independent of glutamate-glutamine cycle activity in cerebellar neuronal-astrocytic cultures. J Neurosci Res 79: 88-96

Basselin M, Robert-Gero M 1998. Alterations in membrane fluidity, lipid metabolism, mitochondrial activity, and lipophosphoglycan expression in pentamidineresistant Leishmania. Parasitol Res 84: 78-83.

Bradford M 1976. A rapid and sensitive method for the quantization of microgram quantities of protein utilizing the principle of protein-dye binding. Anal Biochem 72: 248-254.

Broman J, Hassel B, Rinvik E, Ottersen O 2000. Biochemistry and anatomy of transmitter glutamate. In: Ottersen O, Storm-Mathisen J (Edts.).Glutamate. Elsevier, Amsterdam, pp. 1-44.

Cardoso S, Santana I, Swerdlow R, Oliveira C 2004. Mitochondria dysfunction of Alzheimer's disease cybrids enhances A $\beta$ toxicity. $J$ Neurochem 89: 1417-1426

Ceccon M, Giusti P, Facci L, Borin G, Imbesi M, Florean M, Skaper S 2000. Intracellular glutathione levels determine cerebellar granule neuron sensitivity to excitotoxic injury by kainic acid. Brain Res 862 : 83-89.

Choo Y, Johnson G, MacDonald M, Detloff P, Lesort M 2004. Mutant huntingtin directly increases susceptibility of mitochondria to the calcium-induced permeability transition and cytochrome c release. Hum. Mol Gen 13: 1407-1420.

Danbolt N 2001. Glutamate uptake. Prog Neurobiol 65: $1-105$.

Ellman G 1959. Tissue sulfhydryl group. Arch Biochem Biophys 82: 70-77. 
Fallarero A, Loikkanen J, Männistö P, Castañeda O, Vidal A 2003. Effects of aqueous extracts of Halimeda incrassata (Ellis) Lamouroux and Bryothamnion triquetrum (S.G.Gmelim). Howe on hydrogen peroxide and methyl mercury induced oxidative stress in GT1-7 mouse hypothalamic immortalized cells. Phytomedicine 10: 39-47.

Forman M, Trojanowski J, Lee V 2004. Neurodegenerative diseases: a decade of discoveries paves the way for therapeutic breakthroughs. Nat Med 10: 1055-1063.

Freshney R, Freshney M 1996. Culture of Immortalized Cells. Wiley-Liss, INC., weinheim. pp. 329-344.

Gibbs M, O’Dowd B, Hertz L, Robinson S, Sedman G, Ng K 1996. Inhibition of glutamine synthetase activity prevents memory consolidation. Cognitive Brain Res 4: 57-64.

Gouget B, Sergeant C, Llabador Y, Simonoff M 2001. Bionormalizer: An anti-cancer drug for neuroblastoma?. Nuclear Instruments and Methods in Physics Research Section B: Beam Interactions with Materials and Atoms 181: 470-474.

Hassel B, Brathe A 2000. Neuronal pyruvate carboxilation support formation of transmitter glutamate. $J$ Neurosci 20: 1342-1347.

Hynd M, Scott H, Dodd P 2004. Glutamate-mediated excitotoxicity and neurodegeneration in Alzheimer's disease. Neurochem Int 45: 583-595.

Kemp J, McKernan R 2002. NMDA receptor pathways as drug targets. Nat Neurosci Suppl. 5: 1039-1042.

Le Tutour B 1990. Antioxidative activities of alga extracts, synergistic effect with vitamin E. Phytochemistry 29: 3759-3765.

Nakagawa T, Zhu H, Morishima N, Li E, Xu J, Yankner B, Yuan J 2000. Caspase-12 mediates endoplasmicreticulum-specific apoptosis and cytotoxicity by amyloid- $\beta$. Nature 406: 98-103.

Roth M 1971. Fluorescence reaction for amino acids. Anal Chem 43: 880-882.

Sato M, Nakano T, Takeuchi M, Kanno N, Nagahisae E, Sato Y 1996. Distribution of neuroexcitatory amino acids in marine algae. Phytochemistry 42: 1595-1597.

Sepkuty J, Cohen A, Eccles C, Rafiq A, Behar K, Ganel R, Coulter D, Rothstein J 2002. A neuronal glutamate transporter contributes to neurotransmitter GABA synthesis and Epilepsy. J Neurosci 22: 6372-6379.

Sheu J, Huang S, Duh CH 1996. Cytotoxic oxygenated desmosterols of the red alga Galaxaura marginata. J Nat Prod 59: 23-26.

Smith M, Sayre L, Monnier V, Perry G 1995. Radical ageing in Alzheimer's disease. Trends Neurosci 18: 172-176.

Veitch K, Hombroeckx A, Caucheteux D, Pouleur H, Hue L 1992. Global ischaemia induces a biphasic response of the mitochondrial respiratory chain. Biochem $J$ 281: 709-715. 